\title{
QUALITY ATTRIBUTES OF CONCENTRATED YOGURT (LABNEH) OF GOATS' MILK FORMULATED WITH WHEY PROTEIN POWDER DURING STORAGE
}

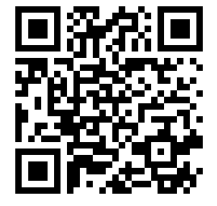

\author{
Limia S. Elssadig 1, Elgasim A. Elgasim 1, Elfadil E. Babiker ${ }^{* 1}$ 四 \\ ${ }^{*}$ Faculty of Agriculture, University of Khartoum, Department of Food Science and Technology, \\ Khartoum North 13314, Shambat, Sudan
}

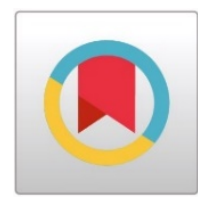

DOI: https://doi.org/10.29121/granthaalayah.v8.i7.2020.679

Article Type: Research Article

Article Citation: Limia S. Elssadig, Elgasim A. Elgasim, and Elfadil E. Babiker. (2020). QUALITY ATTRIBUTES OF CONCENTRATED YOGURT (LABNEH) OF GOATS' MILK FORMULATED WITH WHEY PROTEIN POWDER DURING STORAGE. International Journal of Research -GRANTHAALAYAH, 8(7), 298-307.

https://doi.org/10.29121/granthaa layah.v8.i7.2020.679

Received Date: 07 July 2020

Accepted Date: 30 July 2020

Keywords:

Goat Milk

WPP

Labneh

Lactose

Total Soluble Solids

\section{ABSTRACT}

Background: Whey is a by-product and a good source of milk proteins, lactose, some minerals such as calcium, and soluble vitamins, which make such a by-product, be considered as a source of valuable nutrients and act as a functional food. This study was carried out to investigate the quality attributes of concentrated yogurt (Labneh) made of goats' milk and different concentrations of whey protein powder (WPP).

Methods: Three different formulations were made by mixing goat milk with different concentrations of WPP $(0,5$, and $10 \%)$ and stored for different periods $(0,10$, and 21 days $)$ at $4 \pm 10 \mathrm{C}$. Standard methods were applied to determine the Physico-chemical, microbiological, and sensory parameters of Labneh.

Results: The addition of WPP caused an increase in yield, chemical composition especially protein content and total solids (TS) with the minor effect of the storage periods. The microbial load of labneh decreases with an increase in WPP concentration except for lactic acid bacteria but significantly $(\mathrm{P} \leq 0.05)$ increased with the storage periods. The addition of WPP to goat milk improved organoleptic quality scores.

Conclusion: The production of Labneh with both goats' and WPP showed that this mixture is an interesting opportunity to have a product rich in nutrients and considered satisfactory by consumers.

\section{INTRODUCTION}

Goat (Capra hircus) is a domesticated animal for the production of milk, meat, and wool particularly in different climatic regions including arid, semi-tropical, or mountainous countries [1]. Goats have several roles to play in economic, nutrition, and social aspects [2]. The milk of goats plays a significant role in the economy and survival of people of many countries in the world especially developing countries such as South America, Asia, Africa, and the Middle East [3]. Goat's milk protein is more digestible [4] and less allergenic peptides [5]. Similarly, the fat of goat milk is more digestible [6] and may be considered as an excellent source of energy, for use in various metabolic processes and even for combating metallic diseases [5], [6]. The milk of goats and its products are useful as functional foods, keeping nourishment and health for young and elderly, especially those who are allergic to cow milk [7]. Milk whey is an important source of lactose, calcium, milk proteins, and soluble vitamins, which make this product be

(C) 2020 The Author(s). This is an open access article distributed under the terms of the Creative Commons Attribution License, which permits unrestricted use, distribution, and reproduction in any medium, provided the original author and source are credited. 
considered as a functional food and a source of valuable nutrients [8]. The nourishment of whey as a functional food with high nutrients elevated it to be a co-product in the processing of cheese [8]. The analysis of milk showed that it had two primary sources of protein, the caseins, and whey, after processing of milk the caseins are the proteins responsible for curds making, while whey remains in an aqueous environment [7]. Whey is an important dietary protein supplement that provides antimicrobial activity, modulation of immune, muscle strength and body composition improvement, and prevention of cardiovascular diseases and osteoporosis [8]. The analysis of whey showed that it contained alpha-Lacto albumin, beta-lactoglobulin, bovine serum albumin, immune globulins, lactoferrin, lactoperoxidase enzymes, glycol macro peptides, lactose, and minerals [8]. Concentrated yogurt (Labneh) is a partial solid fermented produced after removing part of the whey from yogurt with a total solid content ranged from 23 to $25 \mathrm{~g} / 100 \mathrm{~g}$ and with fat ranged from 8 to $11 \mathrm{~g} / 100 \mathrm{~g}$, and is considered as an intermediate product between fermented milk and immature cheeses with high moisture content [9]. Concentrated yogurt (Labneh) is an acceptable fermented milk product in many countries especially the Middle East, which has a significant role in family nutrition [10]. Labneh characterized by having a cream or white color, soft and smooth body, good spreadability and flavor, and slight acidity [11]. A study showed that concentrated yogurt (Labneh) has protein content 2.5 times higher, 50\% more minerals, and a considerably larger number of viable microorganisms than common yogurt [11]. Moreover, labneh lactose concentration is low due to its fermentation into lactic acid, which makes it more suitable for use by lactose-intolerant individuals, and its perceived nutritional benefits and shelf-life characteristics have led to its increasing economic importance [11]. This study aimed to investigate the quality attributes of concentrated yogurt (Labneh) made of goats' milk and different concentrations of whey protein powder (WPP).

\section{MATERIALS AND METHODS}

\subsection{MATERIALS}

Fresh goat milk was purchased from Khartoum North farm, Whey protein powder was obtained from the cheese industry, Khartoum, Sudan. All chemicals used in this study were of reagent grade.

\subsection{METHODS}

\subsubsection{PREPARATION OF LABNEH}

Concentrated yogurt (Labneh) was made by the procedure commonly used in homes. Fresh goat's milk was boiled for a few minutes to destroy bacterial cells and fungi, cooled to $45 \mathrm{oC}$ and divided equally into 3 parts then whey protein powder was added at concentrations of 0,5 and $10 \%$ to each part, mixed thoroughly in sterile glass containers, and inoculated with $2 \%$ starter culture and stirred to distribute it through the milk mass. The mixtures were incubated at $43^{\circ} \mathrm{C}$ for $3 \mathrm{hrs}$ until it was completely coagulated and then transferred to clean cheesecloth bags and placed in a hanging cloth bag to drain the whey in the refrigerator at $4 \pm 1^{\circ} \mathrm{C}$ for $18 \mathrm{hrs}$. The resultants coagulated was mixed thoroughly with $0.5 \% \mathrm{NaCl}$ and poured into three small plastic containers. The samples were stored at $4 \pm 1^{\circ} \mathrm{C}$ for 0,10 , and 21 days. At the end of each storage, period samples were taken from each treatment and subjected to microbiological and physicochemical analysis.

\subsubsection{TOTAL YIELD DETERMINATION}

Yield (\%) of Labneh was calculated by equation according to AOAC Method [12].

$$
\text { Yield } \%=\frac{\text { Weight of labneh }}{\text { Weight of milk }} \times 100
$$




\subsubsection{CHEMICAL COMPOSITION}

The AOAC methods [12] were applied to determine moisture, crude protein, fat, and ash contents.

\subsubsection{LACTOSE DETERMINATION}

The method of Teles et al. [13] was used to determine lactose (\%). Dry lactose standard solution in distilled water (\%) was used to estimate the lactose content in formulated and unformulated concentrated yogurt using a colorimeter (Corning Scientific Products, New York, USA) at 520nm.

\subsubsection{DETERMINATION OF TOTAL SOLIDS}

According to the method of AOAC [12] the total solid (TS) content of concentrated yogurt was determined. The total solid (TS) content was calculated using the following equation:

$$
\mathrm{TS} \%=\frac{\mathrm{W} 2}{\mathrm{~W} 1} \times 100
$$

Where W1 and W2 are the weights of the sample before and after drying, respectively.

\subsubsection{TITRATABLE ACIDITY}

The method of Bradley et al. [14] was used to determine the titratable acidity (TA) of concentrated yogurt. The TA was calculated using the following equation:

$$
\mathrm{TA} \%=\frac{\mathrm{ml}(\mathrm{NaOH}) \times \mathrm{N}(\mathrm{NaOH}) \times 9}{\text { Weight of Sample }}
$$

Where $\mathrm{N}$ is the normality of $\mathrm{NaOH}$ and 9 is the conversion factor for lactic acid.

\subsection{7. pH MEASUREMENT}

A pH meter probe (Corning Scientific Products, New York, USA) was used to determine the pH of the samples.

\subsubsection{MICROBIOLOGICAL LOAD}

The method of Harrigan [15] was applied to determine the microbial characteristics of yogurt at different periods of storage. The total viable count of bacteria was done using the Quebec colony counter after incubation of the agar plates at $37 \mathrm{oC}$ for 48 hours. E. coli count was done by methylene blue (EMB) agar plates. The plates were incubated at $37^{\circ} \mathrm{C}$ for 48 hours colonies are usually small with a metallic green sheen on (EMB) agar. Coliform bacteria count was carried out by using the Most Probable Number (MPN) technique. MRS medium was used for counting lactic acid bacteria. Yeast and mold's colonies were determined using potato dextrose agar and the plates were incubated at 25-28 oC for 72 hours, then the colonies forming units (cfu) were counted.

\subsubsection{SENSORY EVALUATION OF CONCENTRATED YOGURT}

Semi-trained members males and females panels (30) were requested to check the sensory properties of formulated and unformulated concentrated yogurt on a 5-point hedonic scale. Before to start sample evaluation, training sessions (3) were done to acquaint panelists with the sensory attributes to be evaluated. Participants were requested to evaluate the color, texture, flavor, taste, and overall acceptability of each sample. Scores were measured 
from "like extremely" to "dislike extremely," corresponding to ratings from 5 to 1 , and all tests were done in triplicate at each evaluation interval $(0,10$, and 21 days). Mean scores for each sample and session were calculated as means \pm SD.

\subsubsection{STATISTICAL ANALYSIS}

Data of the parameters measured based on various treatments, storage periods, and their interactions were analyzed using the general linear model (Two-way ANOVA), and statistical differences were estimated using Duncan's multiple range tests. Mean separation was determined using the least significant difference, and data are reported as the mean \pm standard deviation (SD). The significance level was accepted at $\mathrm{P} \leq 0.05$.

\section{RESULTS AND DISCUSSIONS}

\subsection{PHYSICO-CHEMICAL PROPERTIES OF WPP AND YIELD OF LABNEH}

Table 1 shows the physicochemical composition of WPP. The results showed that WPP had high values of total solids, protein, lactose, and ash and with a $\mathrm{pH}$ of 5.7. The results obtained are in agreement with those of Banavara et al. [16], who observed high values of total solids, protein, lactose, and ash in WPP. The yield percent of goat's milk labneh samples significantly $(\mathrm{P} \leq 0.05)$ affected by the addition of WPP. The percent of the yield was significantly (P $\leq 0.05$ ) improved when the level of WPP was increased. The results obtained for yield are similar to those reported by Henriques et al. [17] and Sfakianakis et al. [18] who concluded that the addition of WP concentrate or WPP to fermented products cause an increase in yield percent.

\subsection{EFFECT OF WPP ADDITION AND STORAGE PERIOD ON CHEMICAL COMPOSITION OF LABNEH}

As shown in Table 2, the protein content of concentrated yogurt (labneh) samples increased when the level of WPP was increased. However, the storage period had no significant $(\mathrm{p} \leq 0.05)$ effect on protein content. The results are similar to those reported by Hamad et al. [19] and Delikanli \& Ozcan [20] who observed an increase in total solids, protein, lactose and ash after addition of whey protein to fermented milk products. The concentrated yogurt (labneh) fat content was neither affected by the level of added whey protein nor the storage period, this mainly because WPP had low-fat content as reported by Mehanna et al [21] and John and phillip [22]. Ash contents of goat's milk labneh slightly increased by the addition of WPP and with the storage period. Similar results were reported by Tamime and Robinson [23] and John and phillp [22] who observed a decrease in moisture content during storage which caused a slight increase in ash content of yogurt, strained yogurt and drinks yogurt. The lactose content of concentrated yogurt (labneh) was observed to increase significantly ( $p \leq 0.05$ ) with the addition of WPP, but decreased significantly ( $\mathrm{p} \leq 0.05$ ) with the storage period. The decrease during storage could be due to the conversion of lactose to acids during fermentation. The results are in the line of John and phillip [22] who concluded that the addition of whey protein to yogurt causes an increase in lactose and ash contents. Sodini et al [24] reported that a decrease in lactose and an increase in titratable acidity of yogurt could be due to the action of lactic acid bacteria which convert lactose to lactic acid during fermentation.

\subsection{PHYSICOCHEMICAL PROPERTIES OF CONCENTRATED YOGURT (LABNEH)}

Table 3 showed the physic-chemical properties of concentrated yogurt (labneh) formulated with whey protein powder (WPP) during storage. The total solid of goat's milk labneh significantly ( $\mathrm{s} \leq 0.05)$ increased with increasing the concentration of WPP but the storage period increased slightly. The results are similar to those observed by John and phillip [22] who reported that the addition of whey protein caused an increase in total solid of yogurt, strained yogurt (labneh), drinkable yogurt and cheese. The results also are similar to the findings of Sandide-Alogu and Oner [9], who stated that the total solid of labneh ranged from 23 to $25 \%$ and fat content $8-11 \%$. The titratable acidity of goat's milk labneh significantly $(\mathrm{p} \leq 0.05)$ affected by the level of WPP and storage period. The titratable acidity of labneh samples decreased with the increase of WPP but the storage period significantly increased it. The results agree with that reported by Mehanna et al [21] who stated that the increase in titratable acidity and decrease in pH 
Quality Attributes of Concentrated Yogurt (Labneh) Of Goats' Milk Formulated with Whey Protein Powder During Storage

value of yogurt might be due to lactose metabolism. Kesenkas et al. [25] stated that the increase in titratable acidity during the storage period as a result of change cause during the fermentation process. Lee and lucey, [26], concluded that the addition of whey protein powder slower the rate of lactic acid bacteria found in the starter culture. Tamime and Robinson [23] stated that the $\mathrm{pH}$ decrease could be responsible for the variability of titratable acidity, besides the acid production indirectly related to lactose metabolism by the yoghurt starter culture. The $\mathrm{pH}$ value of the goat's milk labneh was significantly ( $\leq \leq 0.05)$ affected by the level of whey protein powder and storage period. As shown the pH Values were increased with WPP concentration but decreased during the storage period. The results agree with the findings of Tamime and Robinson [23] who concluded that the pH value was slightly increased when yogurt was fortified with whey protein.

\subsection{EFFECT OF WPP ON MICROBIOLOGICAL QUALITY OF GOAT'S MILK LABNEH}

As shown in Table 4, the total bacterial count (TBC) of goat's milk labneh samples was significantly ( $\mathrm{p} \leq 0.05$ ) affected by the level of WPP and storage period. The TBC decreased with the increase in the level of added WPP. However, the TBC was significantly ( $\mathrm{p} \leq 0.05)$ increased during storage. The results agree with the findings of Tamime and Robinson [23] who concluded that a decrease in TBC might be due to antimicrobial activity WPP. Irrespective of the storage period, there was an inverse relationship between TBC and WPP level. As the level of WPP increased the TBC decreased reaching it is the lowest count $(4.63 \log 10 \mathrm{cfu} / \mathrm{g})$. Also, irrespective of the WPP level used, there was a linear relationship between the storage period and TBC. The count increased $(p \leq 0.05)$ from 4.03 (on day 1 of storage to $6.73 \log 10 \mathrm{cfu} / \mathrm{g}$ on day 21 . The results showed that while none of the whey treated samples (5\% and $10 \%)$ showed any Coliform bacterial growth, the control sample observed to contain such kind of bacteria and significantly ( $\mathrm{p} \leq 0.05$ ) increased with storage. The absence of Coliform bacteria in yogurt with WPP could be attributed to the antibacterial activity of WPP. E. coli was not detected in all labneh samples under test including the control. This is an indication of hygienic processing conditions. The results are in line with the findings of Tamime and Robinson [23] and Mehanna et al [21] who concluded that WPP had antimicrobial activity against pathogenic bacteria. Lactic acid bacteria of goat's milk labneh samples were influenced by the level of WPP and storage period. The lactic acid bacteria count increased with the increase in the WPP level. The storage period significantly increased lactic acid bacteria. Irrespective of whey protein powder treatment, the numbers of lactic acid bacteria increased significantly $(\mathrm{p} \leq 0.05)$ with the increase of storage period reaching its peak $(7.33 \log 10 \mathrm{cfu} / \mathrm{g})$ on the last day of storage period (day 21). Also, irrespective of the storage period the number of lactic acid bacteria increased significantly ( $\leq 0.05)$ with the increase in WPP concentration reaching its peak $(6.40 \log 10 \mathrm{cfu} / \mathrm{g})$ at $5 \%$ WPP. The results showed that while none of the whey treated samples (5\% and $10 \%)$ showed any yeast or molds growth, the control sample observed to contain such kind of microbes and significantly $(\mathrm{p} \leq 0.05)$ increased with storage period. The absence of yeast and molds in yogurt with WPP could be attributed to the antimicrobial activity of WPP as reported by Tamime and Robinson [23] and Mehanna et al. [21].

\subsection{EFFECT OF WPP ADDITION ON SENSORY PROPERTIES OF GOAT'S MILK LABNEH}

The sensory characteristics of concentrated yogurt (labneh) were significantly ( $\mathrm{p} \leq 0.05)$ influenced by the level of whey protein powder as shown in Table 5. Sensory characteristics such as color, texture, taste, flavor, and overall acceptability score increased with the increase of the level of added whey protein powder. The panelists rated all the sensorial properties tested of labneh treated with WPP better than those of the control. The results obtained agree with the findings of Tamime and Robinson [23] and John and phillip [22] who concluded that the addition of WPP improved appearance, texture, and flavor of fermented milk products such as yogurt and cheese. The results also in the line of the finding of Lee and Lucey [26] who stated that yogurt supplementation with whey protein improved appearance, texture, and flavor and extended the shelf life of the product. Pinto et al, [27] reported a positive effect of whey protein powder on yogurt firmness and viscosity. John and Philip [22] and Mehanna et al. [21] concluded that the ability to retain water in yogurt containing whey protein is better than those enriched with skim milk powder. Tamime and Robinson [23] reported that the addition of whey protein powder shortened incubation time and extended shelf life and improved the overall acceptance of yogurt, texture quality, and prevented the whey separation defect. Lee and lucey [26] revealed that whey separation from milk takes place as a result of curd shrinking and affected by the change in the water holding capacity. They also stated that the addition of whey protein 
powder to milk pause positive influence on curd stability and decrease whey separation. Pinto et al [27] and Mehanna et al. [21] speculated that the highest score of sensory properties of yogurt supplementation with whey protein is due to the presence of antimicrobial and inhibiting growth factor and both could lead to shelf life extension. Moreover, they stated that when solids of whey protein replace skim milk powder to stabilize yogurt, improvement of texture and flavor can result. The hydrolysis of the yogurt component by microorganisms during storage was the main deteriorating factor concerning taste, color, flavor, and texture [28], with notable differences between plain and treated yogurt concerning color and flavor intensity. Generally, the results suggested that color, flavor, and texture were the most important attributes that determined the overall acceptability of formulated yogurt. The texture of the plain yogurt showed a decrease with the storage, while the treated one showed an increase.

Table 1: Physicochemical composition of whey protein powder and yield of concentrated yogurt

\begin{tabular}{|c|c|}
\hline Parameter & WPP \\
\hline Total solids (\%) & $97.5 \pm 0.19$ \\
\hline Protein (\%) & $12.20 \pm 0.08$ \\
\hline Lactose (\%) & $75.0 \pm 0.16$ \\
\hline Fat (\%) & $0.50 \pm 0.01$ \\
\hline Ash (\%) & $9.8 \pm 0.02$ \\
\hline Titratable acidity (\%) & $0.15 \pm 0.01$ \\
\hline pH & $5.7 \pm 0.02$ \\
\hline WPP concentration (\%) & Yield (\%) \\
\hline 0 & $32.2 \mathrm{c} \pm 0.28$ \\
\hline 5 & $40.8 \mathrm{~b} \pm 0.34$ \\
\hline 10 & $43.8 \mathrm{a} \pm 0.49$ \\
\hline
\end{tabular}

Values are means of triplicate samples $( \pm \mathrm{SD})$ on dry eight values.

Table 2: Chemical composition and lactose content (\%) of concentrated yogurt (labneh) formulated with whey protein powder (WPP) during storage.

\begin{tabular}{|c|c|c|c|}
\hline \multirow[t]{2}{*}{ Chemical composition/ Storage period (days) } & \multicolumn{3}{|c|}{ WPP concentration (\%) } \\
\hline & 0 & 5 & 10 \\
\hline \multicolumn{4}{|c|}{ Protein } \\
\hline 0 & $10.10^{\mathrm{bA}} \pm 0.05$ & $10.71^{\mathrm{bA}} \pm 0.03$ & $11.30^{\mathrm{aA}} \pm 0.05$ \\
\hline 10 & $10.25^{\mathrm{bA}} \pm 0.04$ & $10.82^{\mathrm{bA}} \pm 0.07$ & $11.62^{\mathrm{aA} \pm 0.09}$ \\
\hline 21 & $10.32^{\mathrm{bA}} \pm 0.04$ & $10.95^{\mathrm{bA}} \pm 0.06$ & $11.79 \mathrm{aA} \pm 0.08$ \\
\hline \multicolumn{4}{|c|}{ Fat } \\
\hline 0 & $8.01^{\mathrm{aA}} \pm 0.01$ & $8.2^{\mathrm{aA}} \pm 0.02$ & $8.4^{\mathrm{aA}} \pm 0.06$ \\
\hline 10 & $8.02^{\mathrm{aA}} \pm 0.03$ & $8.14^{\mathrm{aA}} \pm 0.07$ & $8.16^{\mathrm{aA}} \pm 0.01$ \\
\hline 21 & $8.10^{\mathrm{aA}} \pm 0.02$ & $8.17 \mathrm{aA} \pm 0.01$ & $8.19^{\mathrm{aA}} \pm 0.02$ \\
\hline \multicolumn{4}{|c|}{ Ash } \\
\hline 0 & $0.81^{\mathrm{bA}} \pm 0.12$ & $0.83^{\mathrm{bA}} \pm 0.15$ & $0.94^{\mathrm{aA}} \pm 0.13$ \\
\hline 10 & $0.83^{\mathrm{bA}} \pm 0.03$ & $0.89 \mathrm{bA} \pm 0.07$ & $0.96^{\mathrm{aA}} \pm 0.11$ \\
\hline 21 & $0.85^{\mathrm{bA}} \pm 0.09$ & $0.92^{\mathrm{aA}} \pm 0.14$ & $0.99^{\mathrm{aA}} \pm 0.12$ \\
\hline \multicolumn{4}{|c|}{ Lactose } \\
\hline 0 & $4.27 \mathrm{bA} \pm 0.02$ & $4.68^{\mathrm{bA}} \pm 0.03$ & $5.19 \mathrm{aA} \pm 0.02$ \\
\hline 10 & $4.19 \mathrm{bA} \pm 0.03$ & $4.46^{\mathrm{bA}} \pm 0.04$ & $5.05^{\mathrm{aA}} \pm 0.03$ \\
\hline 21 & $4.05^{\mathrm{aA}} \pm 0.10$ & $4.28^{\mathrm{aA}} \pm 0.03$ & $4.75^{\mathrm{aA} \pm 0.02}$ \\
\hline
\end{tabular}

Values are means of triplicate samples ( \pm SD). Means not sharing a common superscript(s) a, b, or $c$ in a row or $\mathrm{A}, \mathrm{B}$, or $\mathrm{C}$ in a column are significantly different at $\mathrm{P} \leq 0.05$ as assessed by Duncan's Multiple Range Test. 
Table 3: Physicochemical properties of concentrated yogurt (labneh) formulated with whey protein powder (WPP) during storage.

\begin{tabular}{|c|c|c|c|}
\hline \multirow[t]{2}{*}{ Parameters/ Storage period (days) } & \multicolumn{3}{|c|}{ WPP concentration (\%) } \\
\hline & 0 & 5 & 10 \\
\hline \multicolumn{4}{|c|}{ Total solids } \\
\hline 0 & $23.2^{\mathrm{cA}} \pm 0.08$ & $26.59 \mathrm{bA} \pm 0.12$ & $29.28^{\mathrm{aA}} \pm 0.17$ \\
\hline 10 & $23.65^{\mathrm{cA}} \pm 0.2$ & $26.87 \mathrm{bA} \pm 0.22$ & $29.81^{\mathrm{aA}} \pm 0.25$ \\
\hline 21 & $23.92^{\mathrm{cA}} \pm 0.19$ & $27.20^{\mathrm{bA}} \pm 0.21$ & $30.35^{\mathrm{aA}} \pm 0.24$ \\
\hline \multicolumn{4}{|c|}{ Titratable acidity } \\
\hline 0 & $1.56^{\mathrm{aA}} \pm 0.06$ & $1.42^{\mathrm{abA} \pm 0.02}$ & $1.38^{\mathrm{bA} \pm 0.03}$ \\
\hline 10 & $1.67 \mathrm{aA} \pm 0.06$ & $1.48^{\mathrm{abA}} \pm 0.07$ & $1.41^{\mathrm{bA}} \pm 0.06$ \\
\hline 21 & $1.79^{\mathrm{aA}} \pm 0.02$ & $1.51^{\mathrm{aA}} \pm 0.03$ & $1.46^{\mathrm{aA}} \pm 0.05$ \\
\hline \multicolumn{4}{|c|}{$\mathrm{pH}$} \\
\hline 0 & $4.04^{\mathrm{aA}} \pm 0.03$ & $4.22^{\mathrm{aA} \pm 0.05}$ & $4.30^{\mathrm{aA} \pm 0.06}$ \\
\hline 10 & $3.90^{\mathrm{bA}} \pm 0.02$ & $4.17 \mathrm{abA} \pm 0.04$ & $4.25^{\mathrm{aA}} \pm 0.05$ \\
\hline 21 & $3.81^{\mathrm{aA}} \pm 0.02$ & $4.13^{\mathrm{aA}} \pm 0.04$ & $4.20^{\mathrm{aA} \pm 0.05}$ \\
\hline
\end{tabular}

Values are means of triplicate samples $( \pm S D)$. Means not sharing a common superscript(s) $a$, b, or $c$ in a row or $\mathrm{A}, \mathrm{B}$, or $\mathrm{C}$ in a column are significantly different at $\mathrm{P} \leq 0.05$ as assessed by Duncan's Multiple Range Test.

Table 4: Microbiological characteristics of concentrated yogurt (labneh) formulated with whey protein powder (WPP) during storage.

\begin{tabular}{|c|c|c|c|}
\hline \multirow[t]{2}{*}{ Microbial strains/ Storage period (days) } & \multicolumn{3}{|c|}{ WPP concentration (\%) } \\
\hline & 0 & 5 & 10 \\
\hline \multicolumn{4}{|c|}{ total bacterial count $\log 10 \mathrm{cfu} / \mathrm{g}$} \\
\hline 0 & $4.8^{\mathrm{aC}} \pm 0.16$ & $3.9 \mathrm{bc} \pm 0.14$ & $3.4 \mathrm{bC} \pm 0.11$ \\
\hline 10 & $6.7 \mathrm{aB} \pm 0.25$ & $5.2^{\mathrm{bB}} \pm 0.23$ & $4.5^{\mathrm{cB}} \pm 0.18$ \\
\hline 21 & $7.8^{\mathrm{aA}} \pm 0.29$ & $6.4^{\mathrm{bA}} \pm 0.21$ & $6.0^{\mathrm{bA} \pm 0.21}$ \\
\hline \multicolumn{4}{|c|}{ Coliform (MPN/g) } \\
\hline 0 & $6.0^{\mathrm{C}} \pm 0.25$ & N D & N D \\
\hline 10 & $8.0^{\mathrm{B}} \pm 0.02$ & $\mathrm{~N} \mathrm{D}$ & $\mathrm{N} \mathrm{D}$ \\
\hline 21 & $10.0^{\mathrm{A}} \pm 0.02$ & N D & $\mathrm{ND}$ \\
\hline \multicolumn{4}{|c|}{ E. coli $(\mathrm{MPN} / \mathrm{g})$} \\
\hline 0 & N D & N D & N D \\
\hline 10 & N D & N D & N D \\
\hline 21 & $\mathrm{~N} \mathrm{D}$ & N D & N D \\
\hline \multicolumn{4}{|c|}{ Lactic acid bacteria $(\log 10 \mathrm{cfu} / \mathrm{g})$} \\
\hline 0 & $4.6^{\mathrm{aC}} \pm 0.13$ & $4.8^{\mathrm{aC}} \pm 0.17$ & $5.0^{\mathrm{aC}} \pm 0.14$ \\
\hline 10 & $5.9^{\mathrm{bB}} \pm 0.19$ & $6.2^{\mathrm{abB} \pm 0.15}$ & $6.6^{\mathrm{aB} \pm 0.12}$ \\
\hline 21 & $7.0^{\mathrm{aA}} \pm 0.14$ & $7.4^{\mathrm{aA}} \pm 0.18$ & $7.6^{\mathrm{aA}} \pm 0.11$ \\
\hline \multicolumn{4}{|c|}{ yeast and mold $(\log 10 \mathrm{cfu} / \mathrm{g})$} \\
\hline 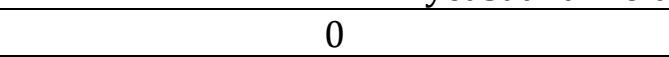 & $5.0^{\mathrm{C}} \pm 0.01$ & $\mathrm{~N} \mathrm{D}$ & N D \\
\hline 10 & $7.0^{\mathrm{B}} \pm 0.02$ & N D & N D \\
\hline 21 & $10.0^{\mathrm{A}} \pm 0.02$ & N D & N D \\
\hline
\end{tabular}

Values are means of triplicate samples $( \pm$ SD). Means not sharing a common superscript(s) a, b, or $c$ in a row or $\mathrm{A}, \mathrm{B}$, or $\mathrm{C}$ in a column are significantly different at $\mathrm{P} \leq 0.05$ as assessed by Duncan's Multiple Range Test. ND $=$ not detected. 
Table 5: Sensory evaluation of concentrated yogurt (labneh) formulated with whey protein powder (WPP) during storage.

\begin{tabular}{|c|c|c|c|}
\hline \multirow[t]{2}{*}{ Sensory attributes/ Storage period (days) } & \multicolumn{3}{|c|}{ WPP concentration (\%) } \\
\hline & 0 & 5 & 10 \\
\hline \multicolumn{4}{|c|}{ Color } \\
\hline 0 & $4.0^{\mathrm{bA}} \pm 0.02$ & $4.3 b^{a A} \pm 0.04$ & $4.5^{\mathrm{aA}} \pm 0.02$ \\
\hline 10 & $3.3^{\mathrm{aB}} \pm 0.01$ & $3.4^{\mathrm{aB} \pm 0.01}$ & $3.5^{\mathrm{aB} \pm 0.02}$ \\
\hline 21 & $3.1^{\mathrm{aB}} \pm 0.02$ & $3.2^{\mathrm{a}} \pm 0.05$ & $3.4^{\mathrm{aB} \pm 0.02}$ \\
\hline \multicolumn{4}{|c|}{ Texture } \\
\hline 0 & $4.1^{\mathrm{aA}} \pm 0.02$ & $4.4^{\mathrm{aA}} \pm 0.97$ & $4.6^{\mathrm{aA}} \pm 0.29$ \\
\hline 10 & $3.6^{\mathrm{aB} \pm 0.05}$ & $3.7 \mathrm{aB} \pm 0.04$ & $3.5^{\mathrm{aB} \pm 0.04}$ \\
\hline 21 & $3.2^{\mathrm{aB}} \pm 0.04$ & $3.4^{\mathrm{a}} \pm 0.07$ & $3.2^{\mathrm{aB}} \pm 0.02$ \\
\hline \multicolumn{4}{|c|}{ Taste } \\
\hline 0 & $4.0^{\mathrm{aA}} \pm 0.01$ & $4.5^{\mathrm{aA}} \pm 0.02$ & $4.7 \mathrm{aA} \pm 0.02$ \\
\hline 10 & $3.1^{\mathrm{bB}} \pm 0.03$ & $3.3^{\mathrm{bB}} \pm 0.04$ & $4.5^{\mathrm{aB}} \pm 0.02$ \\
\hline 21 & $3.0^{\mathrm{aB}} \pm 0.12$ & $3.1^{\mathrm{aB}} \pm 0.14$ & $3.5^{\mathrm{aB} \pm 0.13}$ \\
\hline \multicolumn{4}{|c|}{ Flavor } \\
\hline 0 & $4.0^{\mathrm{bA} \pm 0.01}$ & $4.5^{\mathrm{ab}} \mathrm{A} \pm 0.02$ & $4.7^{\mathrm{aA}} \pm 0.12$ \\
\hline 10 & $3.5^{\mathrm{aB}} \pm 0.14$ & $3.2^{\mathrm{aB}} \pm 0.15$ & $3.5^{\mathrm{aB} \pm 0.16}$ \\
\hline 21 & $3.1^{\mathrm{aB}} \pm 0.21$ & $3.0^{\mathrm{a} B} \pm 0.04$ & $3.3^{\mathrm{aB}} \pm 0.02$ \\
\hline \multicolumn{4}{|c|}{ Overall acceptability } \\
\hline 0 & $4.03^{\mathrm{aA}} \pm 0.01$ & $4.4^{\mathrm{aA}} \pm 0.03$ & $4.6^{\mathrm{aA} \pm 0.22}$ \\
\hline 10 & $3.1^{\mathrm{aB}} \pm 0.13$ & $3.3^{\mathrm{a}} \pm 0.14$ & $3.4^{\mathrm{aB}} \pm 0.02$ \\
\hline 21 & $3.0^{\mathrm{aB}} \pm 0.12$ & $3.0^{\mathrm{aB}} \pm 0.04$ & $3.2^{\mathrm{aB}} \pm 0.32$ \\
\hline
\end{tabular}

Values are means of triplicate samples $( \pm$ SD). Means not sharing a common superscript(s) a, b, or $c$ in a row or $\mathrm{A}, \mathrm{B}$, or $\mathrm{C}$ in a column are significantly different at $\mathrm{P} \leq 0.05$ as assessed by Duncan's Multiple Range Test.

\section{CONCLUSIONS}

The increase in total solid and protein by the addition of whey protein powder significantly improved the ability of labneh to hold water which facilitates gel formation and improves the texture surface properties as well as lactic acid production. The overall quality of labneh made from goat milk can be greatly improved by the addition of whey powder with better physicochemical and organoleptic properties. Incorporation of whey protein powder in labneh and other dairy products can be very interesting not only concerning the yield but also concerning the functional properties of final products and can help the industry increase sales of the dairy product. It is possible to utilize whey protein powder in the manufacture of cheap good quality labneh instead of skim milk powder. Further studies are needed to highlight the benefits and cost of incorporation of whey protein powder in the labneh industry.

\section{SOURCES OF FUNDING}

This research received no specific grant from any funding agency in the public, commercial, or not-for-profit sectors.

\section{CONFLICT OF INTEREST}

The author have declared that no competing interests exist.

\section{ACKNOWLEDGMENT}

None. 
Quality Attributes of Concentrated Yogurt (Labneh) Of Goats' Milk Formulated with Whey Protein Powder During Storage

\section{REFERENCES}

[1] Morand-Frhed, P. Proposal for improving the research efficiency in goat. Small Ruminant Research, 66, 2004, 145-153.

[2] Boyazoglu, J., Hatziminaoglou, I., and Morand-Fehr, P. The role of the goat in society: past, present and perspectives for the future. Small Ruminant Research, 60(1-2), 2005, 13-23.

[3] Albenzio, M., and Santillo, M. Biochemical characteristics of ewe and goat milk: Effect on the quality of dairy products. Small Ruminant Research, 101, 2011, 33-40.

[4] Haenlein, G. F. W. Goat milk in human nutrition. Small Ruminant Research, 51, 2004, 155-163.

[5] Sanz-Sampelayo, M. R., Chilliard, Y., Schmidely, P. H. and Boza J. Influence of type of diet on the fat constituents of goat and sheep milk. Small Ruminant Research, 68, 2007, 42-46.

[6] Vargas, M., Chafer, M., Albors, A., Chiralt, A. and Gonzalez- Martinez, C. Physicochemical and sensory characteristics of yoghurt produced from mixtures of cows' and goat's milk. International Dairy Journal, 18, 2008, 1146-1152.

[7] Albenzio, M., Caroprese, M., Marino, R., Muscio, A., Santillo, A. and Sevi, A. Characteristics of Garganica goat milk and Cacioricotta cheese. Small Ruminant Research, 64, 2006, 35-44.

[8] Walzem, R. L., Dillard C. J. and German, J. B. Whey components: millennia of evolution create functionalities for mammalian nutrition: what we know and what we may be over looking. Critical Review of Food Science and Nutrition, 42, 2002, 353-375.

[9] Sanlidere-Aloglu, H., and Öner, Z. The effect of treating goat's milk with trans glutaminase on chemical, structural and sensory properties of Labneh. Small Ruminant Research, 109, 2013, 31-37.

[10] Abd El-Salam, M.H., Hippen, A. R., El-Shafie, K., Assem, F. M., Abbas, H., Ab El-Aziz, M., Shraf, O. and El-Aassar, M. Preparation and properties of probiotic concentrated yoghurt (labneh) fortifited with conjugated linoleic acid. International Journal of food Science \&Technology, 46 (10), 2011, 1365-2621.

[11] Nsabimana, C., Jiang, B. and Kossah, R. Manufacturing, properties and shelf life of Labneh: A review. International Journal of Dairy Technology, 58(3), 2005, 129-137.

[12] AOAC. Association of official analytical chemist. Official methods of analysis, 17th ed. Washington, DC, USA. 2003.

[13] Teles, F. F., Young, C. K., and Stull, J. W. A method for rapid determination of lactose. Journal of Dairy Science, 61(4), 1978, 506-508.

[14] Bradley, R. L., Arnold, J. E., Barbano, J. D., Semerad, R. G., Smith, D. E., \& Vines, B. K. Chemical and Physical Method: In Standard Method for the Examination of Dairy Products, (Ed.) Marshall, RT, American Public Health Ass., (APHA). New York, USA, 1992, 433.

[15] Harrigan, W.F. Laboratory methods in food microbiology. (3rd edn), Academic press, California, USA, 1998, 533-540.

[16] Banavara, D. S., Annpama, D. and Rankin, S. A. Studies on physicochemical and functional properties of whey protein powder, Journal of Dairy science, 86, 2003, 3866-3865.

[17] Henriques, M. H., Gomes, D. M., Pereira, C. J., and Gil, M. H. Effects of liquid whey protein concentrate on functional and sensorial properties of set yogurts and fresh cheese. Food and Bioprocess Technology, 6(4), 2013, 952-963.

[18] Sfakianakis, P., Özer, B., Varzakas, T., and Tzia, C. 6 Dairy Product Technology. Handbook of Food Processing: Food Safety, Quality, and Manufacturing Processes, 35, 2015, 179.

[19] Hamad, M. N., Ismail, M. M., and Basiony, M. M. Effect of fortification with whey protein on the chemical, microbial and organoleptical properties of Labneh. Journal of Food and Dairy Sciences, 5(11), 2014, 751-762.

[20] Delikanli, B., and Ozcan, T. Effects of various whey proteins on the physicochemical and textural properties of set type nonfat yoghurt. International Journal of Dairy Technology, 67(4), 2014, 495-503.

[21] Mehanna, N. The influence of dried whey protein adding on the quality of functional fermented milk products. Journal of American science, 89, 2012, 21-25.

[22] John, S. and Philip, T. Physical properties of strained yoghurt fortified with whey protein powder. Journal of Science of Food and Agriculture, 25, 2005, 920-926.

[23] Tamime, A. Y. and Robinson, R.K. Yoghurt science and technology 2nd ed. C R press. Boca Ratter P L., 2000.

[24] Sodini, I., Lucas, A., Tissier, J. P., and Corrieu, G. Physical properties and microstructure of yoghurts supplemented with milk protein hydrolysates. International Dairy Journal, 15(1), 2005, 29-35.

International Journal of Research -GRANTHAALAYAH 
[25] Kesenkas, H., Dinkci, N., Seckin, K., Gürsoy, O. and Kınık, O. Physicochemical, Biochemical, Textural and Sensory Properties of Telli Cheese - A Traditional Turkish Cheese Made from Cow Milk. Bulgarian Journal of Agricultural Science, 18(5), 2012, 763-770.

[26] Lee, W. J. and Lucey, J. ARheological properties and microstructure of strained yoghurt, Journal of Texture Studies, 50, 2013, 616-620.

[27] Pinto, S., Rathour, A. K. and Jana, A. H.Utilization of whey protein powder in processed cheese and concentrated yoghurt. Journal of Dairy Science and Technology, 10, 2010, 220-225.

[28] Duboc, P., and Mollet B. Applications of exopoly-saccharides in the dairy industry. International Dairy Journal $11,2001,759-768$. 